\title{
Alteration and Exsolution Characteristics of Ilmenites of Moheskhali Island, Chittagong, Bangladesh
}

\author{
Syed Samsuddin Ahmed ${ }^{\mathrm{a}}$, M. Yunus Miah*b, Chowdhury Qumruzzaman ${ }^{\mathrm{a}}$, M. Nazim Zaman ${ }^{\mathrm{b}}$, A. K. M. \\ Badrul Alam ${ }^{\text {b }}$ and Pradip Kumar Biswas ${ }^{b}$
}

\author{
${ }^{a}$ Department of Geology and Mining, University of Rajshahi, Rajshahi 6205. ${ }^{b}$ Institute of Mining, \\ Mineralogy and Metallurgy, BCSIR, Science Laboratory Road, Khonjonpur, Joypurhat 5900.
}

\begin{abstract}
Mineralogical analysis of Moheskhali beach sands revealed the presence of high amount of ilmenite. About 50\% of these ilmenites are unaltered which are characterized by the presence of exsolution of ilmenite with hematite, ilmenite with magnetite, and ilmenite with rutile. Others (50\%) are unexsolved where 30-50\% grains partially or fully altered. These altered and unaltered phases of ilmenite are confirmed by X-Ray diffraction study. Ilmenite-hematite exsolution comprising $70-80 \%$ of the total exsolution. The widely banded exsolved phases were formed by continuous exsolution mechanism while the second generation thinner bands were formed discontinuously. Seriate texture dominates (about 75\%) over emulsion, granular, quadrangular, sub graphic, veined and special types. Optical study suggests that the alteration of ilmenite is seen to proceed along grain boundaries and/or fractures resulting in an amorphous to microcrystalline mass resembling leucoxene. The chemical composition of the alteration products of ilmenite frequently fluctuates within definite ranges (pseudoilmenite and pseudorutile ranges) of a nonstoichiometric composition and thus deviates from their ideal composition.
\end{abstract}

Key words: Ilmenite, Rutile, Opaque, Exlosution, Alteration.

\section{Introduction}

Ilmenite, the major source of titanium metal receives much attention among basic researchers due to its ubiquitous presence in rocks and sediment which are widely used as pigment, welding electrodes, coating and lining for blast furnace hearth. Alteration phenomenon, intergrowths, ferrousferric ratio and trace element distribution form prime concerns of Geochemists and Mineralogists with reference to this mineral. $\mathrm{TiO}_{2}$ is enriched by all normal weathering process over all rocks, and the amount of enrichment is proportional to the intensity of weathering. Several papers have been published on the alteration of ilmenite. Most of the previous workers (Grey and Reid 1975, Wort and Jones 1981, Choudhury et al. 1989, Gupta et al. 1988, Hugo and Cornell 1991, Suresh Babu et al. 1994, Rao et al. 2002 and 2005) are agreed that the mineral ilmenite undergoes oxidation and leaching whereby iron is removed from the structure resulting in a relative enrichment in $\mathrm{TiO}_{2}$. Most alteration leads to thermodynamically unstable, incomplete, irreversible phases that are extremely complex in elemental composition (Rao et al. 2005). Consequently, the physical and chemical characteristics such as bulk density, porosity, grain density, hardness, magnetic susceptibility and other properties are affected.

Moheskhali Island is 17 miles long and 6 miles wide. The main part of the island is low hills composed of sandstone

\footnotetext{
* Corresponding author: E-mail: pdyuns@yahoo.com
}

and shales of Mio-Pliocene age. The heavy mineral deposits are exposed on the western side slope of the hill range some 3-4 miles inland from the present shore line (Fig. 1) and run more or less parallel to the foothills. The beach sands of Moheskhali Island belong to fine sand class, well sorted to very well sorted and negatively skewed (Mitra and Ahmed, 1990). The heavy minerals of the study area vary from 10 to $20 \%$. Most of the heavy minerals lie within the size fraction of $1.5 \phi$ to $3.5 \phi$ and the percentage increase from $1.5 \phi$ to $3.5 \phi$ size fraction. The non-opaque heavy minerals are hornblende, garnet, epidote, actinolite-tremolite, sillimanite, sphene, zircon, monazite, etc. The opaque minerals content varies between 15 and $30 \%$ of the heavies. These are ilmenite, magnetite, titanomagnetite, hematite, iron-hydroxides, rutile and pyrite

Ilmenite, the main source of titanium of Bangladesh, is the major opaque mineral in the Moheskhali Island. It varies from 15 to 30\% (Mitra and Ahmed, 1990). Both unaltered and altered ilmenites are recognized in the study area and $50 \%$ of the unaltered ilmenite is exsolved (Ahmed et al. 1992). In the present study, ilmenites of Moheskhali Island (Fig. 1) are studied for understanding their exsolution pattern and alteration. 


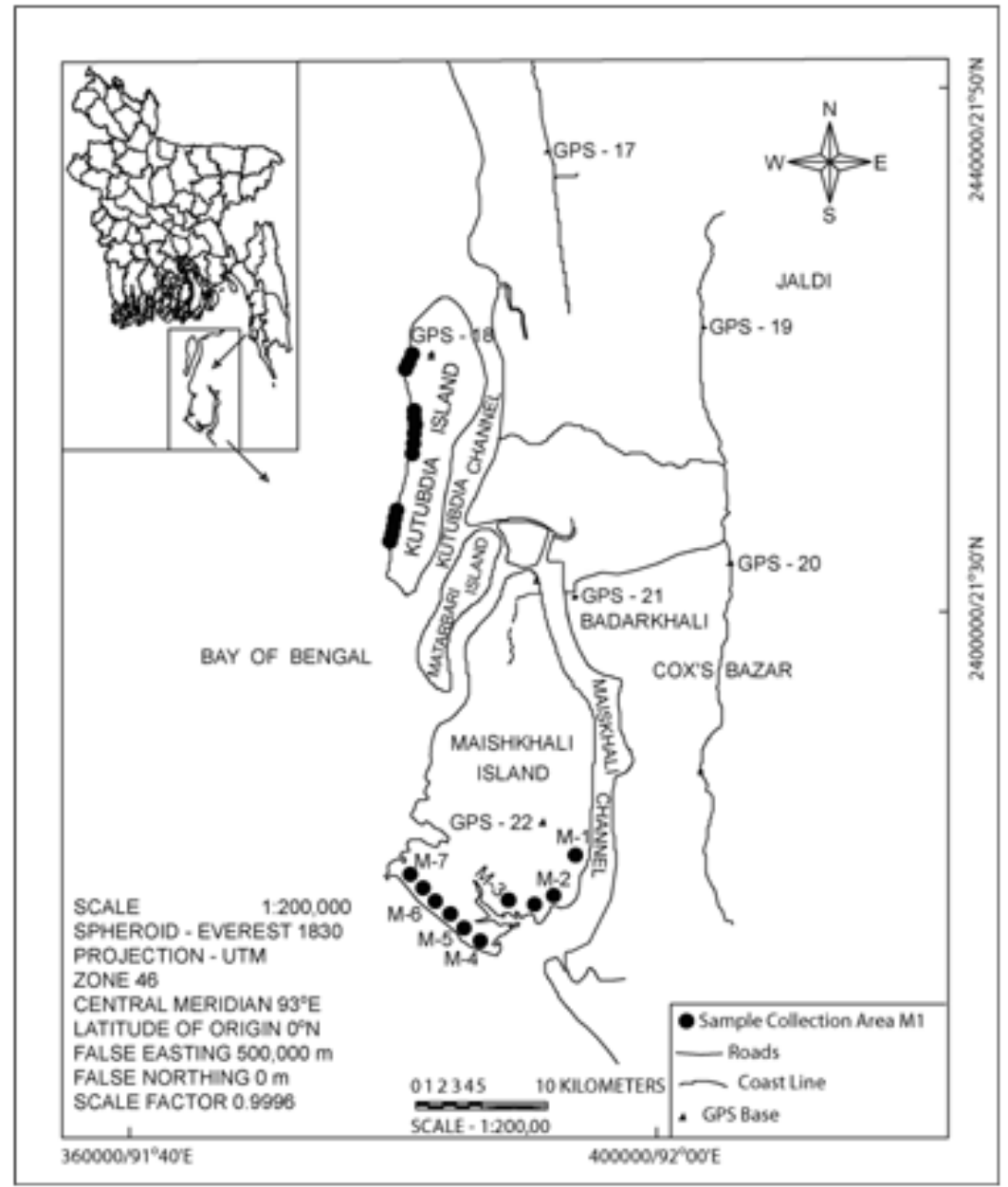

Fig. 1. Index map of Moheshkhali Island showing sample locations.

\section{Methodology}

Representative beach samples were collected from the Moheskhali Island. After washing and drying $100 \mathrm{~g}$ of each sample is sieved through a Ro-tap sieve shaker. The heavy minerals were studied from two size fractions viz 1.5-2.5 $\phi$ and 2.5-3.0 $\phi$ from each sample. The heavy minerals of the fraction were separated using isodynamic magnetic separator, ilmenite and non-magnetic fractions being removed by maintaining the separator with a $25^{\mathrm{O}}$ side slope, a current of $0.3 \mathrm{amp}$. and a tilt of $15^{\mathrm{O}}$ in moderate vibration. For optical studies the grains were mounted in a solidified resin (araldite) and polished. Opaque minerals were studied under ore microscope and non-opaques under polarizing microscope. About 200 grains were counted in each section under a microscope. Bulk chemical analyses were done using atomic absorption spectrophotometer (Perkin Elmer Type2380). The X-Ray analysis was carried out using Philips XRay dilfractometer. For mineral chemistry, ilmenites were analyzed with the help of JEOL-JXA-9600 EPMA superprobe model, with an accelerating voltage of $15 \mathrm{KV}$ with a beam current of $0.01 \mathrm{nA}$ and a diameter of $10 \mu \mathrm{m}$.

\section{Results and Discussion}

\section{Optical microscopy}

\section{Exsolution}

Unaltered ilmenite is brown to pinkish brown in color in contrast to the grayish white, minutely granular, porous appearance of the altered grains. The shape of ilmenite grains ranges from elongated lamellae, prismatic, irregular, subrounded to euhedral. The reflectivity is measured on an average 18.2. About $50 \%$ of the unaltered ilmenite shows a wide variety of exsolution features. Five major types of exsolution in ilmenite have been recognized in Moheskhali beach sand. These are ilmenite-hematite, magnetite-ilmenite, hematite -rutile, ilmenite-hematite-rutile and ilmenite-rutile. 
Among these the most common ( 80\%) exsolution products in the investigated area are the exsolution of ferrianilmenite and titanohematite both simultaneously acting as the host and the guest in the same grain. In most cases, the lamellae of the guest are distributed bimodally (sometimes polymodally) with modes of their thickness clustering around $2 \mu$ and $8 \mu$ (Fig. 2a, 2b, 2c, 3c, 4a, 4b). The distribution of minimum lamellae widths in ilmenite-hematite coexisting phases from the Moheshkhali Island is shown in Table I. These detrital ilmenites with preserved intergrowth are more commonly derived from igneous rather than metamorphic source rocks (Riezebos, 1979). The early generation coarser lamellae were formed at high temperature $\left(600-530^{\circ} \mathrm{C}\right)$ by a fast diffusion process and the finer ones formed at later stages of crystallization by slow diffusion process in the temperature range of $500-430^{\circ} \mathrm{C}$ (Ahmed et al. 1992). Rarely some

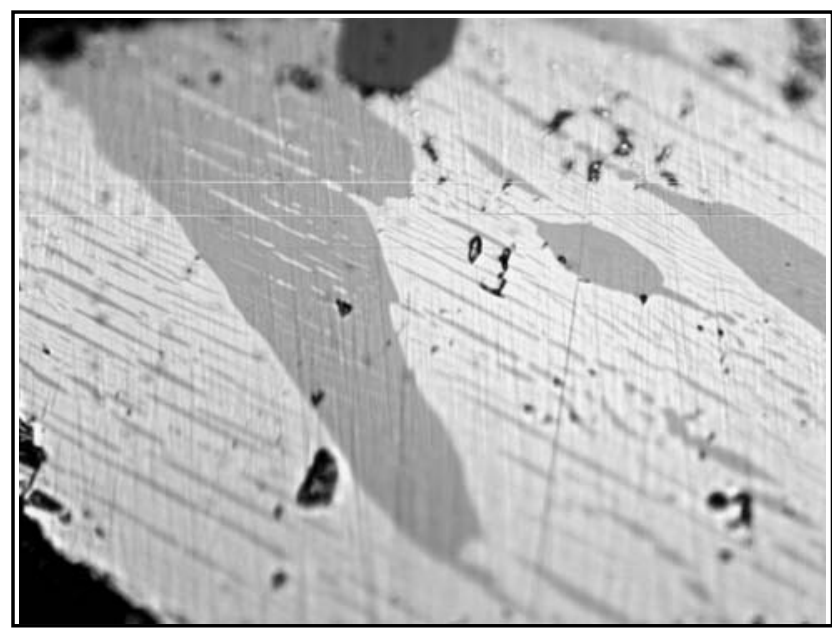

2(a)

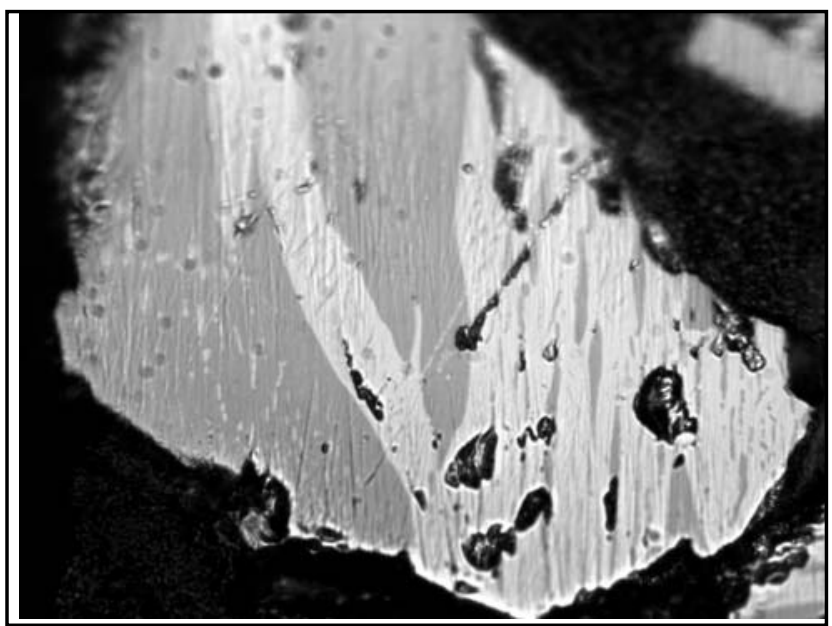

2(c) grains show equal amounts of ilmenite and hematite (Fig. 3c) indicating higher temperature of crystallization by a fast diffusion process (Ramdohr, 1980).

In some hematite (or ilmenite), smaller ilmenite (or hematite) exsolution bodies in parallel rows between the rows of large exsolution bodies of ilmenite (or hematite) are formed (Fig. 2d, 3a). Ilmenites with fine grained exsolution of hematite are also common where the depletion zone or zones of non-exsolution are concentrated along the grain boundaries (Fig. 3b). Sometimes the lamellae in the host shows micro-boudin-like feature (Fig. 3d) indicating its generation in stressed condition.

Pure ilmenite solid solution exsolves by continuous exsolution mechanism but $\mathrm{Fe}_{2} \mathrm{O}_{3}$-rich ilmenite solid-solution

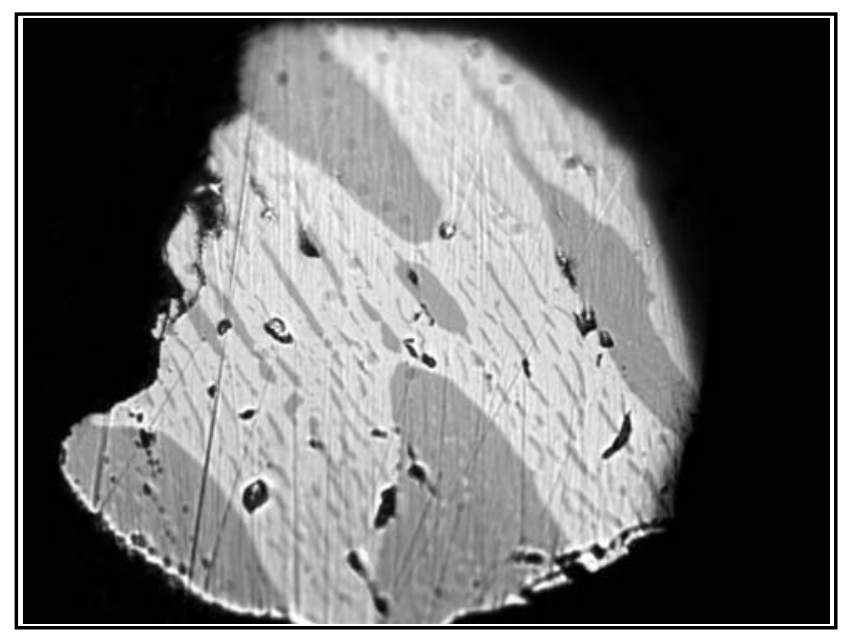

2(b)

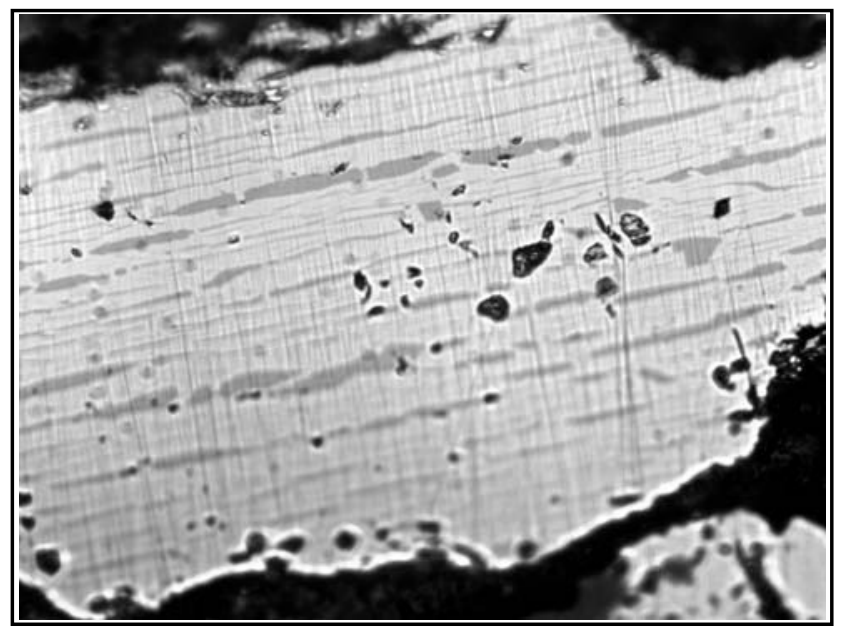

2(d)

Fig. 2. Seriate texture of Ilmenite-Hematite a, b, c) Two generations exsolution lamellae.

d) Finer curved lenses of Ilmenite in hematite which are formed by stress conditions. 
Table I: Distribution of minimum lamellae widths in ilmenite-hematite coexisting phases from study area (in percent)

\begin{tabular}{l|c|c|c|c|c|c}
\hline Sample No & No exsolution & $<1 \mu \mathrm{m}$ & $1-6 \mu \mathrm{m}$ & $6-12 \mu \mathrm{m}$ & $12-20 \mu \mathrm{m}$ & $>20 \mu \mathrm{m}$ \\
\hline M-1 & 57.84 & 3.30 & 21.00 & 12.52 & 3.84 & 1.50 \\
M-2 & 38.00 & 7.08 & 30.08 & 15.72 & 6.60 & 2.52 \\
M-3 & 43.15 & 8.29 & 26.44 & 15.28 & 5.10 & 1.74 \\
M-4 & 51.73 & 5.60 & 24.20 & 13.00 & 5.16 & 2.03 \\
\hline
\end{tabular}

exsolves discontinuously (Kretchsmar and McNutt, 1971, Haggerty, 1976). Exsolution textures in the two phase ilmenite-hematite were formed either by continuous or by discontinuous mechanism and sometimes by both. In Fig. 2a, $2 \mathrm{~b}$ and 2c, the first generation thicker lamellae are formed by continuous mechanism while the second generation thinner lamellae are formed discontinuously. In hemo-ilmenite the exsolved $\mathrm{Hem}_{\mathrm{ss}}$ solute is a relatively evenly distributed single generation constituent. Hematite-rich solid solutions are restricted to acid intrusive and anorthosite suites; where Hemss are seen to exsolve coexisting with ilmenite-rich solid solution (Haggerty, 1976). ilmenite/hematite ratio in exsolved ilmenite is shown in Table II where the average ratio of ilmenite/hematite in exsolved ilmenite is 0.97 . The average percentage of pure ilmenite (exsolved + unexsolved) and pure hematite (exsolved) are found to be $73.74 \%$ and $26.26 \%$ respectively.

\section{X-ray diffraction analyses}

Using the intensity ratios of peaks (104) of ilmenite and hematite, the percentage of hematite and ilmenite in bulk samples are determined with reference to the calibration curve of Kretchmar and McNutt 1971, as shown in Fig. 6. Xray powder diffraction data (Table III) of four ilmenite sam

Table II. Optical modal analysis of exsolved ilmenites from Study area

\begin{tabular}{|c|c|c|c|c|c|c|c|c|c|c|}
\hline \multirow[t]{2}{*}{ Sample no. } & \multirow{2}{*}{$\begin{array}{c}\text { Percentage } \\
\text { of exsolved } \\
\text { ilmenite }\end{array}$} & \multicolumn{7}{|c|}{$\begin{array}{c}\text { Percentage of different types of exsolution textures. The values in the } \\
\text { parenthesis are average ilmenite/hematite ratio. }\end{array}$} & \multirow{2}{*}{$\begin{array}{c}\text { Total ilmenite } \\
\text { (exsolved + } \\
\text { unexsolved) } \\
\%\end{array}$} & \multirow{2}{*}{$\begin{array}{c}\text { Total } \\
\text { hematite } \\
\text { (exsolved) } \\
\text { \% }\end{array}$} \\
\hline & & Seriate & Emulsion & Granular & Sub-graphic & Quadrangular & Veined & Others & & \\
\hline \begin{tabular}{c|}
$\mathrm{M}-2$ \\
$(3.0-4.5 \phi)$
\end{tabular} & 42.16 & $\begin{array}{l}33.68 \\
(0.41)\end{array}$ & $\begin{array}{c}4.22 \\
(0.47)\end{array}$ & $\begin{array}{c}0.69 \\
(0.96)\end{array}$ & $\begin{array}{c}0.42 \\
(0.47)\end{array}$ & $\begin{array}{c}0.42 \\
(1.22)\end{array}$ & $\begin{array}{c}0.63 \\
(0.43)\end{array}$ & $\begin{array}{c}2.10 \\
(0.79)\end{array}$ & 70.80 & 29.20 \\
\hline \begin{tabular}{c|}
$\mathrm{M}-2$ \\
$(1.5-3.0 \phi)$ \\
\end{tabular} & 62.00 & $\begin{array}{l}53.94 \\
(1.24)\end{array}$ & $\begin{array}{c}4.34 \\
(0.61)\end{array}$ & $\begin{array}{c}1.55 \\
(0.64)\end{array}$ & - & $\begin{array}{c}0.93 \\
(0.54)\end{array}$ & $\begin{array}{c}0.62 \\
(0.67)\end{array}$ & $\begin{array}{c}0.62 \\
(0.69)\end{array}$ & 70.93 & 29.07 \\
\hline $\begin{array}{c}\mathrm{M}-4 \\
(3.0-4.5 \phi) \\
\end{array}$ & 56.85 & $\begin{array}{l}44.41 \\
(0.70) \\
\end{array}$ & $\begin{array}{c}6.89 \\
(3.34) \\
\end{array}$ & $\begin{array}{c}1.22 \\
(1.50) \\
\end{array}$ & $\begin{array}{c}1.14 \\
(1.22) \\
\end{array}$ & $\begin{array}{c}0.58 \\
(1.56)\end{array}$ & - & $\begin{array}{c}2.61 \\
(1.13)\end{array}$ & 69.83 & 30.17 \\
\hline $\begin{array}{c}\mathrm{M}-4 \\
(1.5-3.0 \phi) \\
\end{array}$ & 48.27 & $\begin{array}{l}38.49 \\
(0.92) \\
\end{array}$ & $\begin{array}{c}4.88 \\
(1.86) \\
\end{array}$ & $\begin{array}{c}1.49 \\
(1.38) \\
\end{array}$ & $\begin{array}{c}1.20 \\
(0.59) \\
\end{array}$ & - & $\begin{array}{c}0.24 \\
(0.75) \\
\end{array}$ & $\begin{array}{c}1.97 \\
(0.45) \\
\end{array}$ & 75.37 & 24.63 \\
\hline Av.\% present & 51.74 & 43.11 & 4.40 & 1.25 & 0.65 & 0.41 & 0.25 & 1.67 & 73.74 & 26.26 \\
\hline $\begin{array}{c}\text { Av./ilm./he } \\
\text { m ratio }\end{array}$ & & 0.90 & 1.85 & 0.94 & 0.71 & 0.81 & 0.58 & 0.89 & & \\
\hline
\end{tabular}

The exsolved ilmenite of Moheskhali exhibits different types of well developed textural patterns namely seriate (Fig. 2 and 3), emulsion (Fig. 4a and 4b), granular (Fig. 4c and 4d), quadrangular, sub graphic (Fig. 5a), veined and special type (Fig. 5b, 5c and 5d). Seriate type is predominant (about 80\%) where the coarse ilmenite (or hematite) exsolution bodies contain rows of small bodies of hematite (or ilmenite) of various sizes. Modal analysis of exsolved ilmenites from the study area is shown in Table II. These exsolution bodies have the same general orientation parallel to the (0001) direction of the ilmenite and hematite host. In the study area, the average percentage of different textures with their ples of different grain sizes show a general increase of cell parameters with decreasing weight percentage of hematite.

\section{Bulk chemical analysis}

By atomic absorption $\mathrm{Ti}, \mathrm{Fe}, \mathrm{Mn}, \mathrm{Mg}$ and $\mathrm{Cr}$ contents in ilmenites were determined and the results are shown in Table IV. Moheskhali ilmenites contain 39.76 to $42.85 \% \mathrm{TiO}_{2}$ and 23.70 to $28.04 \% \mathrm{Fe}_{2} \mathrm{O}_{3}$. The ratio of ilmenite $\left(\mathrm{FeO}\right.$. $\left.\mathrm{TiO}_{2}\right)$ to hematite $\left(\mathrm{Fe}_{2} \mathrm{O}_{3}\right)$ varies from 2.46 to 3.16. The coarse fraction (1.5-3.0 $\phi)$ is found to contain more $\mathrm{TiO}_{2} \%$ than the finer fraction (3.0-4.5 $\phi$ ). The percentage of $\mathrm{Mn}, \mathrm{Mg}$ and $\mathrm{Cr}$ in ilmenite is insignificant. 


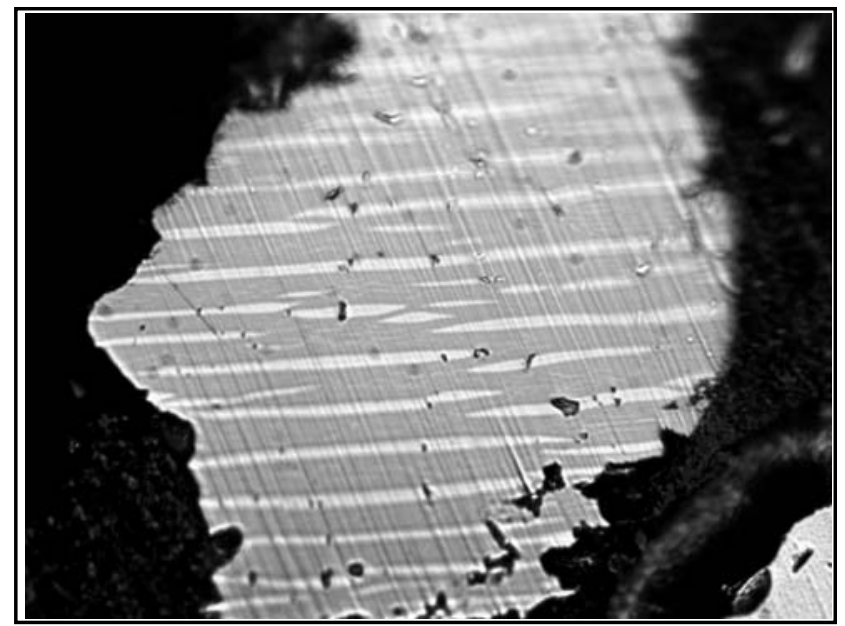

3(a)

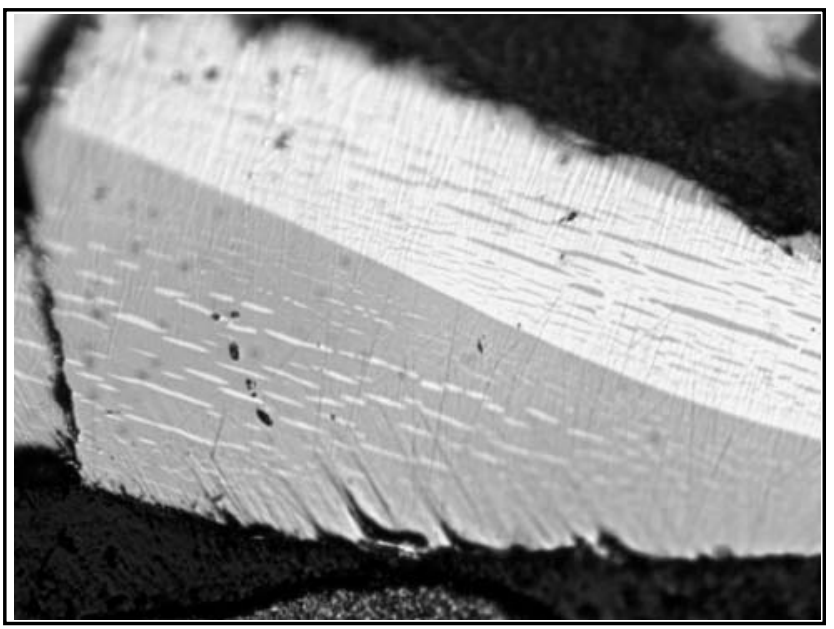

3(c)

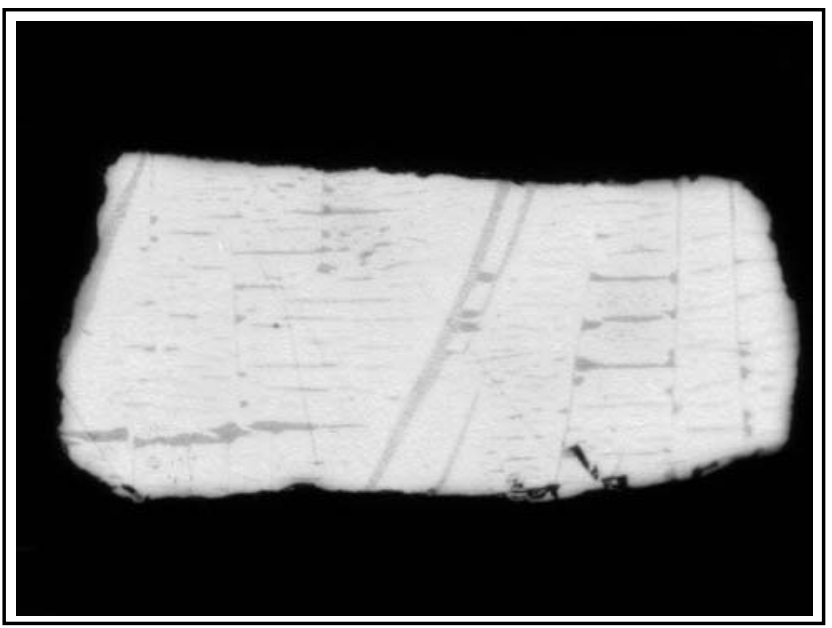

3(b)

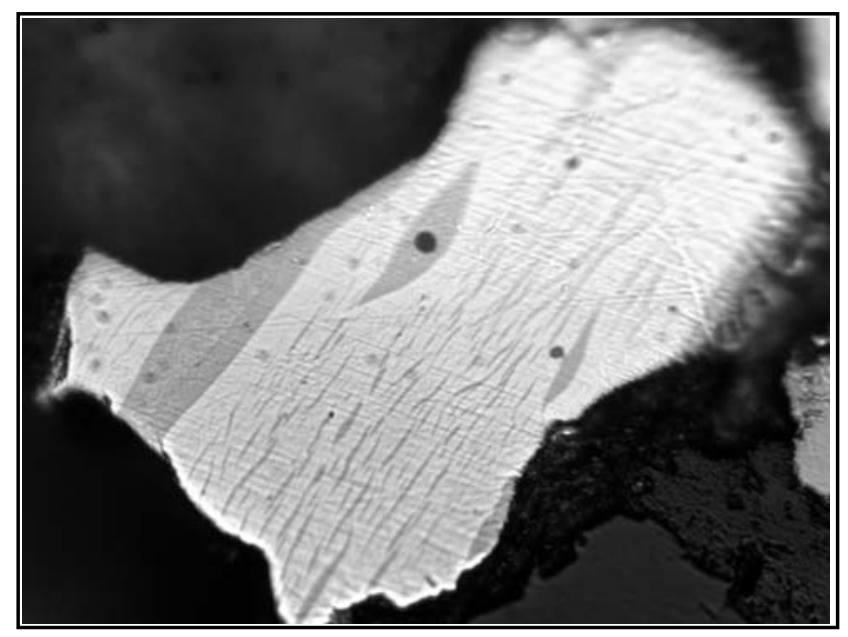

3(d)

Fig. 3. Seriate texture of Ilmenite-Hematite a) Parallel rows of exsolution lamellae of Hematite in Ilmenite. b) Multi generation exsolved phases of Ilmenite in Hematite. c) Equal amount of Hematite and Ilmenite as a decomposition product of a high temperature solutions. d) Two generations Ilmenite exsolution in Hematite host formed by stressed conditions.

\section{Alteration of Ilmenite}

A conspicuous differential response to weathering (chemical action of sea water) has been noted among those with exsolution (hematite + ilmenite) and without (unexsolved). The later shows alteration upto $40 \%$ by volume with the development of leucoxene, pseudorutile etc. while the exsolved ones are almost free from such effects of alteration.In general intergrowth of ilmenite-hematite appears to survive weathering and stand longer transport compared to magnetitehematite; whereas ilmenite-magnetite intergrowths are the least durable (Molinaroli and Basu, 1987). The degree of alteration of different ilmenite deposits in the world is quite varied; those of South Africa and Brazil being altered relatively very little but those of Australia, India and America show extensive alteration. Alteration phenomenon
Table III. Composition of ilmenite separates determined By X-ray diffraction.

\begin{tabular}{l|c|c|c}
\hline Sample & $I_{(104)_{\mathrm{Hem}}} \mathrm{Ilm}_{(104}$ & $\begin{array}{c}\text { wt\% } \\
\text { Hematite }\end{array}$ & $\begin{array}{c}\text { Cell } \\
\text { parameters }(\AA)\end{array}$ \\
\hline $\mathrm{M}-2$ & 1.52 & 28.12 & $\mathrm{a}=5.077$ \\
$(3.0-4.5 \phi)$ & & 26.14 & $\mathrm{a}=5.080$ \\
$\mathrm{M}-2$ & 1.69 & & $\mathrm{c}=14.017$ \\
$(1.5-3.0 \phi)$ & & 27.42 & $\mathrm{a}=5.080$ \\
$\mathrm{M}-4$ & 1.61 & & $\mathrm{c}=14.015$ \\
$(3.0-4.5 \phi)$ & & 23.55 & $\mathrm{a}=5.082$ \\
$\mathrm{M}-4$ & 1.92 & & $\mathrm{c}=14.020$ \\
$(1.5-3.0 \phi)$ & & &
\end{tabular}




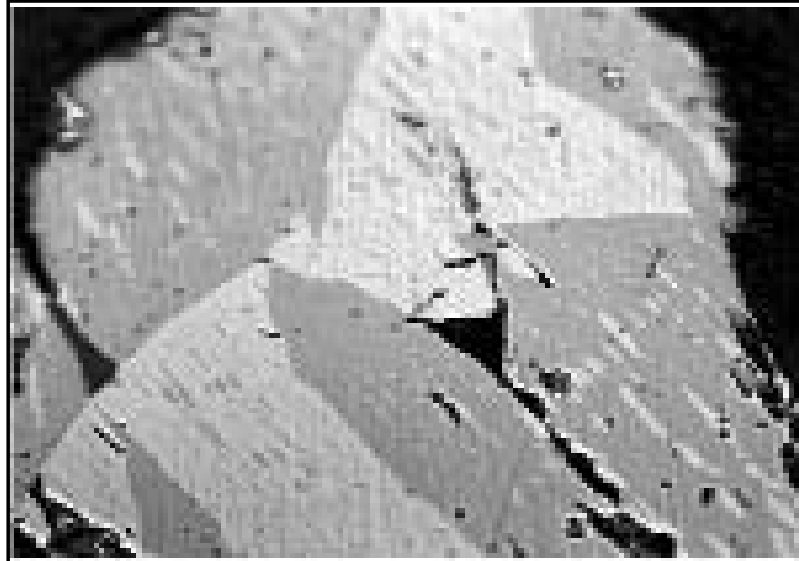

4 (a)

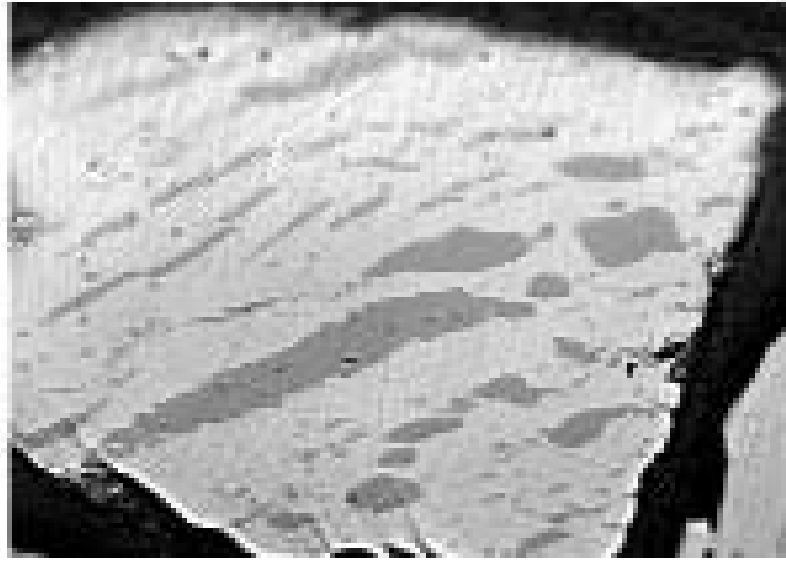

4 (c)

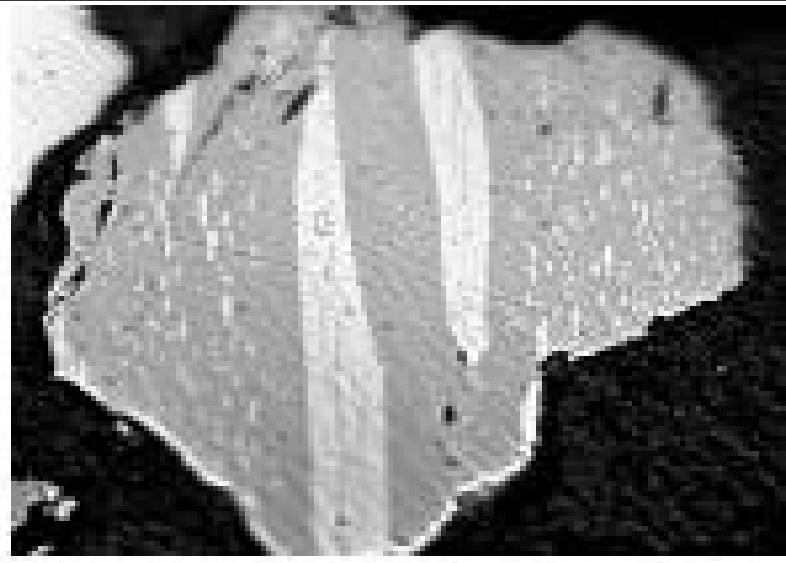

4 (b)

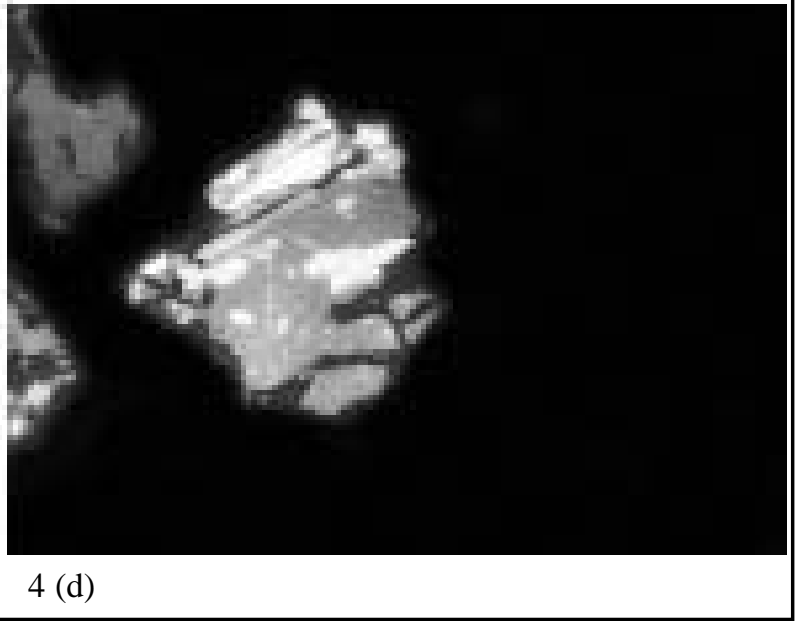

c, d) Granular texture.

ognized viz, pseudoilmenite, pseudorutile and leucoxene. Though ilmenite alteration is neither uniform nor continuous; the alteration in the study area either may be continuously to pseudoilmenite-pseudorutile-leucoxene or directly to leucoxene or to pseudorutile. Table $\mathrm{V}$ shows the reflectiv in the study area is less (10 to $20 \%$ of the total ilmenite) comparative to eastern and southern coast of India (Mitra and Ahmed, 1990). Alteration is seen only in unexsolved ilmenite, while the exsolved ones are almost free from such alteration. In the study area three stages of alteration is rec

Table IV. Bulk Chemical analysis of ilmenites

\begin{tabular}{|c|c|c|c|c|c|c|c|c|}
\hline Sample No. & $\mathrm{TiO}_{2} \%$ & $\mathrm{FeO} \%$ & $\mathrm{Fe}_{2} \mathrm{O}_{3} \%$ & $\mathrm{MnO} \%$ & $\mathrm{MgO} \%$ & $\mathrm{Cr}_{2} \mathrm{O}_{3}$ & $\mathrm{FeO} \mathrm{TiO}_{2} \%$ & $\frac{\mathrm{FeO} . \mathrm{TiO}_{2}}{\mathrm{Fe}_{2} \mathrm{O}_{3}}$ \\
\hline $\begin{array}{l}\text { M-2 } \\
(3.0-4.5 \phi)\end{array}$ & 39.76 & 30.82 & 27.84 & 1.14 & 0.27 & 0.06 & 70.58 & 2.54 \\
\hline $\begin{array}{l}\text { M-2 } \\
(1.5-3.0 \phi)\end{array}$ & 41.35 & 31.96 & 25.31 & 1.17 & 0.04 & 0.02 & 73.31 & 2.89 \\
\hline $\begin{array}{l}\text { M-4 } \\
(3.0-4.5 \phi)\end{array}$ & 39.12 & 29.83 & 28.04 & 1.30 & 0.34 & 0.308 & 68.95 & 2.46 \\
\hline $\begin{array}{l}\text { M-4 } \\
(1.5-3.0 \phi)\end{array}$ & 42.85 & 32.02 & 23.70 & 1.04 & 0.08 & 0.03 & 74.87 & 3.16 \\
\hline
\end{tabular}


Table V. Reflectivity of ilmenite and its alteration products

\begin{tabular}{l|c}
\hline Mineral & Reflectivity \\
\hline Ilmenite & 19.2 \\
Pseudoilmenite & 20.0 \\
Pseudorutile & 21.8 \\
Leucoxene & 23.4 \\
\hline \hline
\end{tabular}

ity of ilmenite and its alteration products. X-ray diffraction data and chemical composition of ilmenite and its alteration products are given in Table VI and Table VII respectively. The chemical composition of the alteration products of ilmenite frequently fluctuates within definite ranges of nonstoichiometric composition and thus deviates from their ideal composition (Table VII)

Pseudoilmenite, the first phase of alteration occurs due the incomplete alteration of ilmenite to pseudorutile. Here patchy intergrowths of both altered and unaltered ilmenite present (Fig. 7). Alteration is taking place from the periph ery, along irregular veins and cracks. It is grey in color and isotropic (Fig. 7). Pseudoilmenite can be replaced by

Table VI. X-ray diffraction data of ilmenite and its alteration products

\begin{tabular}{|c|c|c|c|c|c|c|c|c|c|c|c|c|c|}
\hline \multicolumn{2}{|c|}{ Ilmenite } & \multicolumn{2}{|c|}{$\begin{array}{c}\text { Phase-1 } \\
\text { Pseudoilmenite } \\
\text { M-1 }\end{array}$} & \multicolumn{2}{|c|}{$\begin{array}{c}\text { Phase-1 } \\
\text { Pseudoilmenite } \\
\text { M-2 } \\
\end{array}$} & \multicolumn{2}{|c|}{$\begin{array}{c}\text { Phase-2 } \\
\text { Pseudorutile } \\
\text { M-1 } \\
\end{array}$} & \multicolumn{2}{|c|}{$\begin{array}{c}\text { Phase-2 } \\
\text { Pseudorutile } \\
\text { M-2 } \\
\end{array}$} & \multicolumn{2}{|c|}{$\begin{array}{l}\text { Phase-3 } \\
\text { Leucoxene } \\
\text { M-1 }\end{array}$} & \multicolumn{2}{|c|}{$\begin{array}{c}\text { Phase-3 } \\
\text { Leucoxene } \\
\text { M-2 }\end{array}$} \\
\hline $\mathrm{dA}^{\mathrm{O}}$ & $\mathrm{I} / \mathrm{I}_{1}$ & $\mathrm{dA}^{\mathrm{O}}$ & $\mathrm{I} / \mathrm{I}_{1}$ & $\mathrm{dA}^{\mathrm{O}}$ & $\mathrm{I} / \mathrm{I}_{1}$ & $\mathrm{dA}^{\mathrm{O}}$ & $\mathrm{I} / \mathrm{I}_{1}$ & $\mathrm{dA}^{\mathrm{O}}$ & $\mathrm{I} / \mathrm{I}_{1}$ & $\mathrm{dA}^{\mathrm{O}}$ & $\mathrm{I} / \mathrm{I}_{1}$ & $\mathrm{dA}^{\mathrm{O}}$ & $\mathrm{I} / \mathrm{I}_{1}$ \\
\hline 3.737 & 30 & 3.85 & 30 & 3.722 & 20 & 2.697 & $26(\mathrm{H})$ & 2.690 & $24(\mathrm{H})$ & 3.251 & 100 & 3.242 & 94 \\
\hline 2.754 & 100 & 2.742 & 100 & 2.764 & 100 & 2.751 & 20(IL) & 2.726 & 20(IL) & 2.482 & 38 & 2.784 & 42 \\
\hline 2.544 & 70 & 2.591 & 55 & 2.506 & 50 & 2.480 & 65 & 2.478 & 60 & 2.181 & 14 & 2.170 & 17 \\
\hline 2.237 & 30 & 2.242 & 25 & 2..172 & $10(\mathrm{PR})$ & 2.087 & 36 & 2.060 & 30 & 2.049 & 6 & 2.186 & 10 \\
\hline 1.868 & 40 & 1.802 & 30 & 1.792 & 25 & 1.683 & 100 & 1.672 & 100(IL) & 1.683 & 50 & 1.720 & 55 \\
\hline 1.726 & 55 & 1.770 & 60 & 1.709 & 50 & 1.702 & 12 (IL) & 1.705 & 10(IL) & 1.619 & 18 & 1.624 & 20 \\
\hline 1.635 & 9 & 1.645 & 6 & 1.660 & 8 & 1.476 & 20 & 1.470 & 20 & 1.479 & 4 & 1.468 & 5 \\
\hline 1.506 & 30 & 1.509 & 20 & 1.495 & 25 & 1.441 & 22 & 1.304 & 10 & 1.449 & 10 & 1.442 & 8 \\
\hline 1.469 & 35 & 1.412 & 30 & 1.412 & 20 & 1.362 & 11 & 1.436 & 25 & 1.357 & 13 & 1.361 & 11 \\
\hline \multirow[t]{2}{*}{1.342} & 13 & 1.294 & 10 & 1.352 & 7 & & & & & 1.254 & 9 & & \\
\hline & & \multicolumn{2}{|c|}{$\begin{array}{c}\mathrm{a}_{0}=5.011 \\
\pm 0.02 \mathrm{~A}^{\mathrm{O}} \\
\mathrm{c}_{0}=14.340 \\
\pm 0.012 \mathrm{~A}^{\mathrm{O}}\end{array}$} & \multicolumn{2}{|c|}{$\begin{array}{l}\mathrm{a}_{0}=5.182 \\
\pm 0.016 \mathrm{~A}^{\mathrm{O}} \\
\mathrm{C}_{0}=13.85 \\
\pm 0.027 \mathrm{~A}^{\mathrm{O}}\end{array}$} & \multicolumn{2}{|c|}{$\begin{array}{l}\mathrm{a}_{0}=2.863 \\
\pm 0.034 \mathrm{~A}^{\mathrm{O}} \\
\mathrm{C}_{0}=4.590 \\
\pm 0.042 \mathrm{~A}^{\mathrm{O}}\end{array}$} & \multicolumn{2}{|c|}{$\begin{array}{l}\mathrm{a}_{0}=2.860 \\
\pm 0.016 \mathrm{~A}^{\mathrm{O}} \\
\mathrm{C}_{0}=4.531 \\
\pm 0.028 \mathrm{~A}^{\mathrm{O}}\end{array}$} & \multicolumn{2}{|c|}{$\begin{array}{l}\mathrm{a}_{0}=4.599 \\
\pm 0.017 \mathrm{~A}^{\mathrm{O}} \\
\mathrm{C}_{0}=2.498 \\
\pm 0.031 \mathrm{~A}^{\mathrm{O}}\end{array}$} & & \\
\hline
\end{tabular}

Table VII. Chemical compositions of ilmenite and its alteration products

\begin{tabular}{|c|c|c|c|c|c|c|c|c|c|}
\hline $\begin{array}{l}\text { Sample } \\
\text { No. }\end{array}$ & $\mathrm{FeO}$ & $\mathrm{Fe}_{2} \mathrm{O}_{3}$ & $\mathrm{TiO}_{2}$ & $\mathrm{MnO}$ & $\mathrm{MgO}$ & $\mathrm{Al}_{2} \mathrm{O}_{3}$ & $\begin{array}{c}\mathrm{Fe} / \mathrm{Ti} \text {-molar } \\
\text { ratio }\end{array}$ & Formula & Mineral \\
\hline M-1 & 43.86 & 3.28 & 50.65 & 1.38 & 0.52 & 0.09 & 0.98 & $\left(\mathrm{Fe}_{1.87}^{2+} \mathrm{Mn}_{0.06} \mathrm{Mg}_{0.04} \mathrm{Fe}_{0.10}^{3+}\right) \mathrm{Ti}_{1.93} \mathrm{O}_{6}$ & Ilmenite \\
\hline M-2 & 20.24 & 23.68 & 53.98 & 1.36 & 0.50 & 0.11 & 0.89 & $\left(\mathrm{Fe}_{0.77}^{2+} \mathrm{Mn}_{0.05} \mathrm{Mg}_{0.03} \mathrm{Fe}_{0.83}^{3+}\right) \mathrm{Ti}_{1.93} \mathrm{O}_{6}$ & Pseudoilmenite \\
\hline M-3 & 22.45 & 21.29 & 54.10 & 1.29 & 0.48 & 0.08 & 0.96 & $\left(\mathrm{Fe}_{0.88}^{2+} \mathrm{Mn}_{0.05} \mathrm{Mg}_{0.04} \mathrm{Fe}_{0.77}^{3+}\right) \mathrm{Ti}_{1.93} \mathrm{O}_{6}$ & Pseudoilmenite \\
\hline M-4 & 8.96 & 31.06 & 58.98 & 0.78 & 0.45 & 0.10 & 0.65 & $\left(\mathrm{Fe}_{0.27}^{2+} \mathrm{Mn}_{0.03} \mathrm{Mg}_{0.03} \mathrm{Fe}_{107}^{3+}\right) \mathrm{Ti}_{202} \mathrm{O}_{6}$ & Pseudorutile \\
\hline M-5 & 4.02 & 34.12 & 59.94 & 0.82 & 0.40 & 0.14 & 0.62 & $\left(\mathrm{Fe}_{0.13}^{2+} \mathrm{Mn}_{0.06} \mathrm{Mg}_{0.03} \mathrm{Fe}_{0.02}^{3+}\right) \mathrm{Ti}_{1.17} \mathrm{O}_{6}$ & Pseudorutile \\
\hline M-6 & - & 1.21 & 91.90 & 0.13 & 0.87 & 0.48 & 0.02 & $\left(\mathrm{Mg}_{0.03} \mathrm{Fe}_{0.01}^{2+} \mathrm{Al}_{0.02} \mathrm{Ti}_{0.93} \mathrm{O}_{6}\right.$ & Leucoxene \\
\hline M-7 & - & 0.21 & 98.13 & - & - & 0.40 & 0.004 & $\mathrm{TiO}_{2}$ & Leucoxene \\
\hline
\end{tabular}

* Analyses exclusive of the trace elements $\mathrm{Cr}^{3+}, \mathrm{V}^{3+}$, Ni etc. present in the samples 


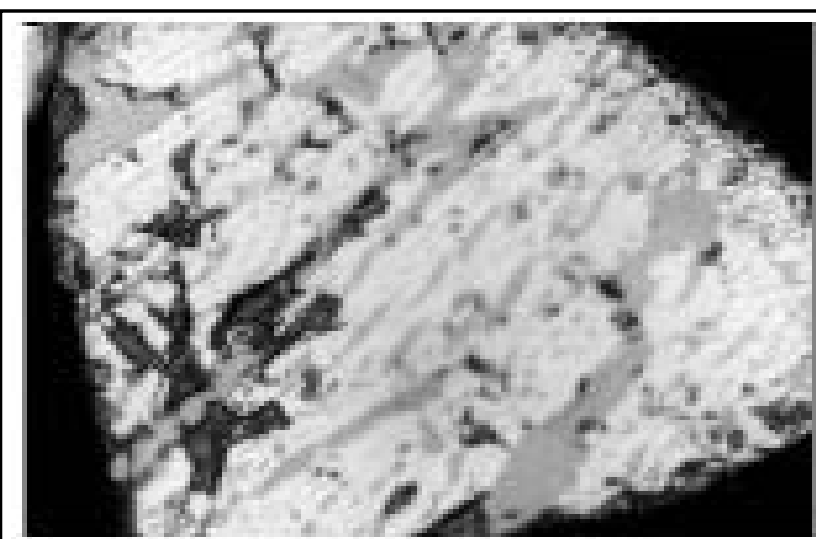

5 (a)

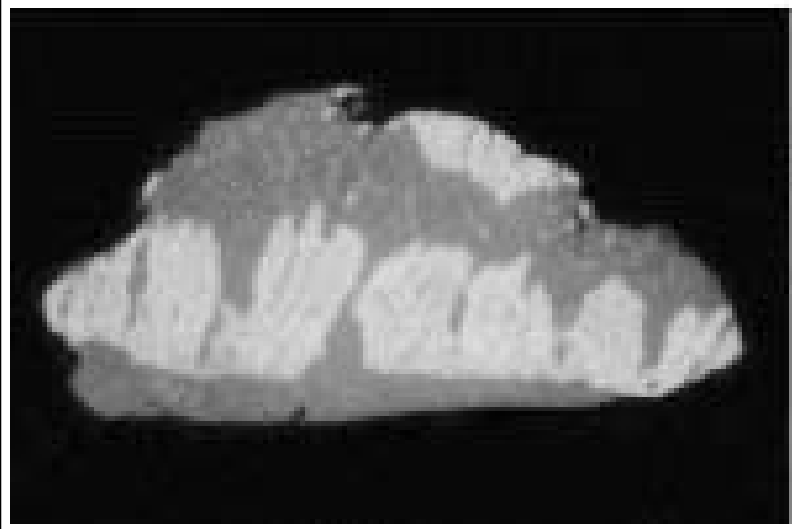

5 (c)

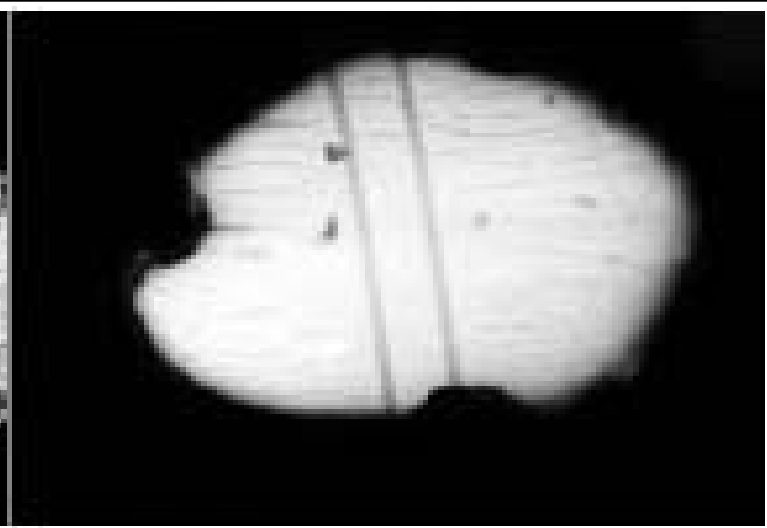

5 (b)

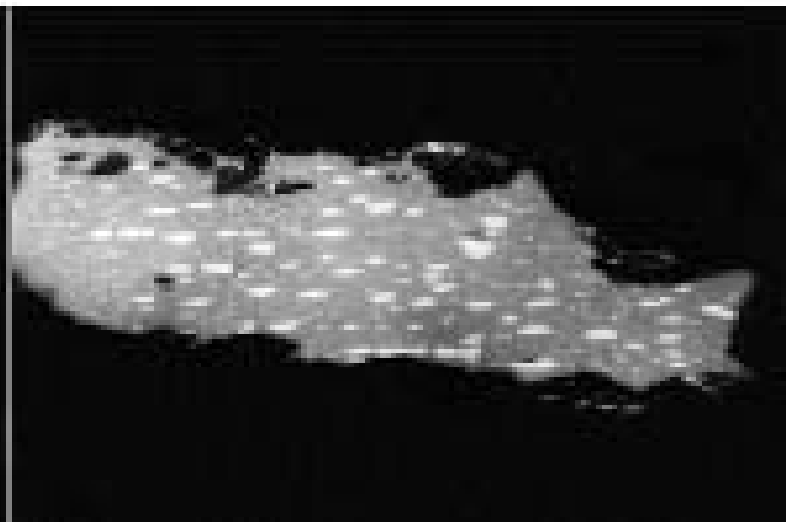

5 (d)

Fig. 5. a) Sub-graphic texture. b) Blitz texture of Hematite-Ilmenite-Rutile. c) Special type - forest fire texture. d) Special type - Deer skin texture.

pseudorutile (Fig. 7) or by leucoxene (Fig. 7). Pseudoilmenite is characterized by the simultaneous presence of bivalent and trivalent iron in its lattice. Its chemical composition may vary within a definite stoichiometric range (Table VII). The decrease of Fe content at this alteration study is accompanied an increase of Ti content and hence the molar ratio of $\mathrm{Fe} / \mathrm{Ti}$ for ilmenite (1.02) decreases to about 0.84 for pseudoilmenite. Both optical and chemical properties of pseudoilmenite are distinctly different from those of ilmenite and pseudorutile, through the X-ray analyses correspond to those of ilmenite (Table VI). The X-ray patterns are diffused.

Pseudorutile is very fine grained, slightly grayer and isotropic nature. The reflectance of pseudorutile is higher than that of pseudoilmenite. The $\mathrm{Fe}_{2} \mathrm{O}_{3}$-content at this stage distinctly predominates over FeO-content (Table VII) and the $\mathrm{Fe} / \mathrm{Ti}$ molar ratio decreases from 0.84 for pseudoilmenite to 0.64

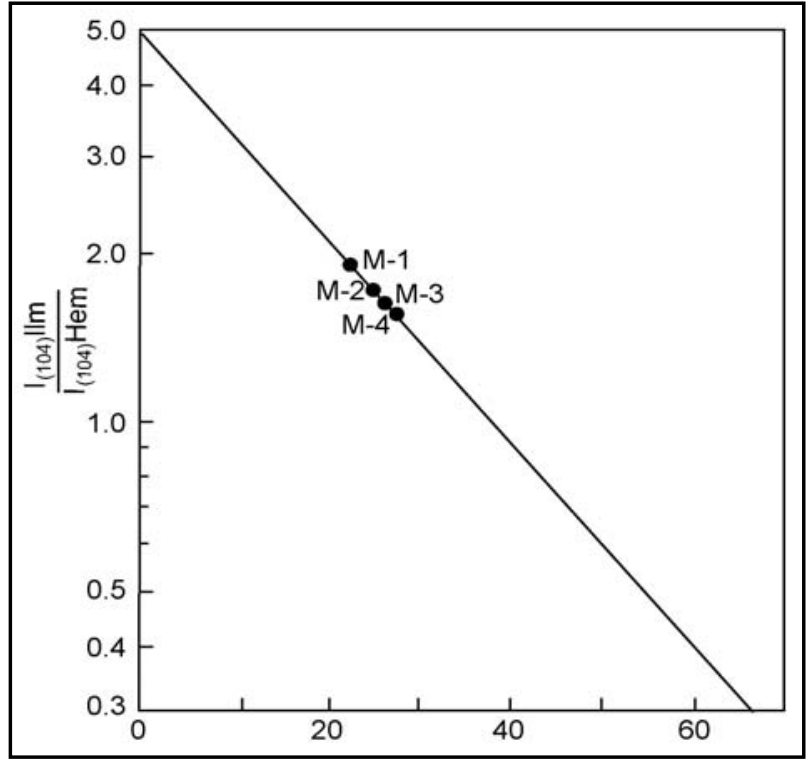

Fig. 6. X-ray deteriminative calibration curve representing ilmenite (104) peak intensity/hematite (104) peak intensity plotted on a logarithmic scale (5\%, uncertainty). 


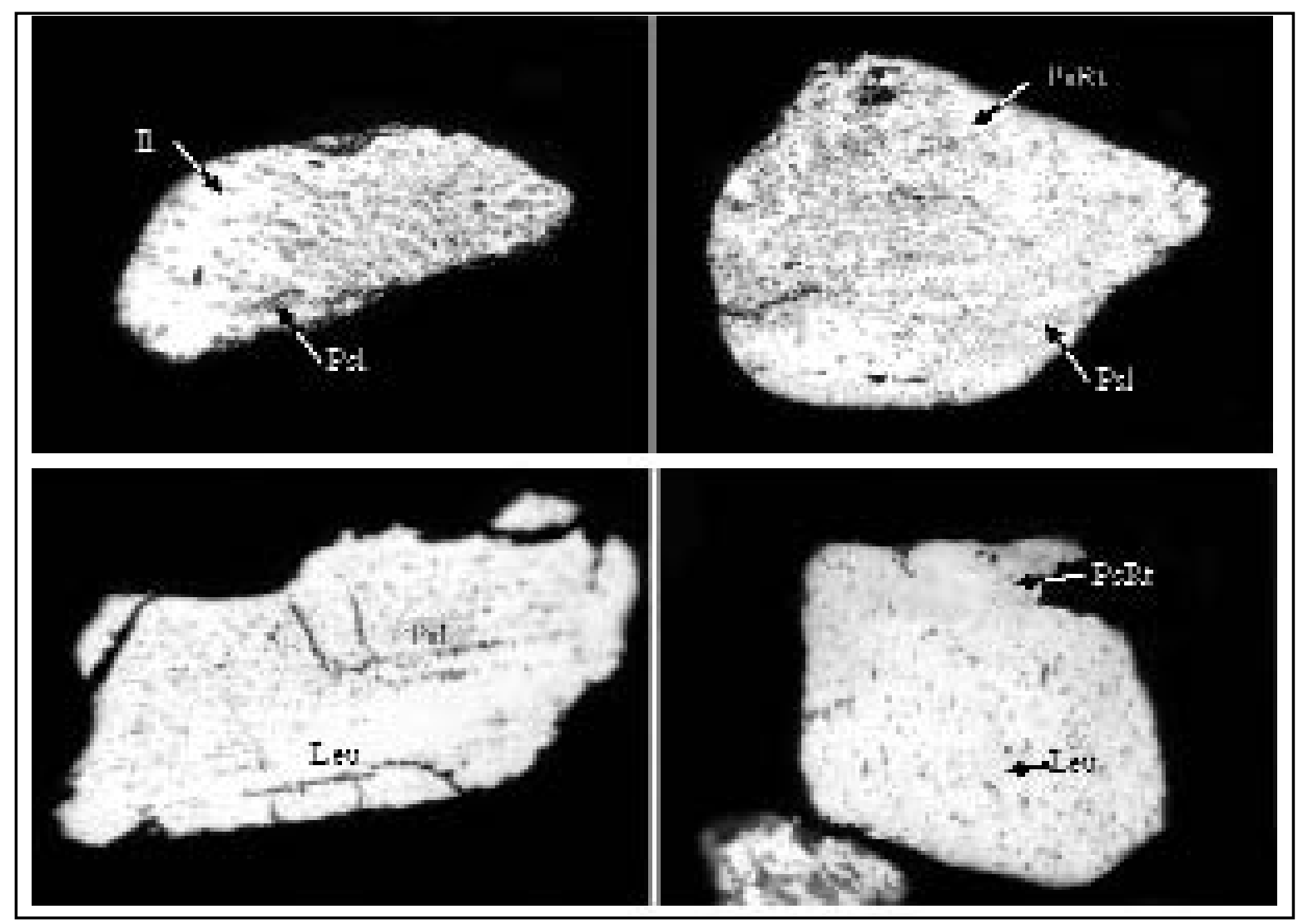

Fig. 7. Alteration of ilmenite a) Ilmenite (Il) is replaced by pseudoilmenite (psl) b) Pseudorutile (Psrt) and pseudoilmenite replaces ilmenite c) Pseudoilmenite is directly altered to leucoxere (Leu) d) In contrast to pseudorutile leucoxene shows yellowsih-white internal reflection

for pseudorutile. With continued removal of iron from the grain, pseudorutile converts to leucoxene either from the core of the grain or along the grain boundaries (Fig. 7). The areas formed of leucoxene are readily distinguished from pseudorutile or pseudoilmenite by their bright internal reflection under cross-nicols. In reflected light leucoxene is cream-colored. Cell volume, when computed from the data in Table III for altered ilmenite, clearly decreases from ilmenite to leucoxene leading to the shrinkage cracks in pseudorutile and leucoxene.

\section{Conclusion}

The major opaque mineral in Moheskhali beach is ilmenite which consists of 10 to $35 \%$ of the total heavies. About $50 \%$ of the unaltered ilmenites exsolves hematites in different textural patterns and due to this reason iron content in the ilmenite concentrate is likely to be more in the study area. About $70 \%$ of the exsolution texture is seriate texture where hematite lamellae in ilmenite and ilmenite lamellae in hematite are exsolved from $\mathrm{FeTiO}_{3}-\mathrm{Fe}_{2} \mathrm{O}_{3}$ solid solution
From the modal analysis, chemical analysis and x-ray study, the percentage of ilmenite (exsolved + unexsolved) and hematite (exsolved) are observed to be $73.74 \%$ and $26.26 \%$ respectively. The widths of lamellae in detrital ilmenites are suggestive of igneous provenance. The widely banded exsolved phases were formed by continuous exsolution mechanism at higher temperature while the second generation thinner bands were formed discontinuously at lower temperature. The unexsolved ilmenites in the study area show alteration along grain boundaries and fractures. This alteration leads to the formation of leucoxene. Chemical analysis indicates enrichment of $\mathrm{TiO}_{2}, \mathrm{MgO}$ and $\mathrm{Al}_{2} \mathrm{O}_{3}$ with loss of iron and $\mathrm{MnO}$. It is also noted that the alteration of ilmenite is not uniform and the extent of alteration varies from grain to grain.

\section{Acknowledgements}

The authors are thankful to the authorities of the Beach Sand Exploration Centre, Cox's Bazar and the Atomic Energy Commission for kindly supplying the separated samples. 
The authors are also thankful to the Department of Geological Sciences, Jadavpur University, India for chemical analysis. Authors are extremely grateful to the other scientist, technicians and laboratory attendants of the institute.

\section{References}

Ahmed S. S., Pal T. and Mitra S. (1992) Ilmenites from Cox's Bazar beach sands, Bangladesh: Their intergrowths. Jour. Geol. Soc. India, 40: 29-41.

Basu A. and Molinaroli E. (1989) Provenance characteristics of detrital opaque Fe-Ti oxide minerals. Jour. Sed. Petrol, 59: 922-934.

Chaudhuri J. N. B., Newesley H. and Chakravorty P. S. (1989) On occurrence of new monazite and ilmenite deposits at coast of Bay of Bengal (near Puri), Orissa, India (Abstract). 28th International Geological Conference, 9-19 July, 1989 Washington, 144-145.

Grey F. A. and Reid A. F. (1975) The structure of pseudorutile and its role in the natural alteration of ilmenite. Am. Mineral, 60: 898-908.

Gupta S. K., Rajakumar V. and Grieveson P. (1988) The influence of weathering on the reduction of ilmenite with carbon. Metal. Trans, 20(B): 735-745.

Haggerty S. E. (1976) Opaque oxide minerals interrestrial igneous rocks. In. Oxide Minerals. MSA Short Course Notes. 3: 101-300.

Hugo V. E. and Cornell D. H. (1991) Altered ilmenites in Holocene dunes from Zululand, South Africa, Petrographic studies for multistage alteration. South Africa Jour. Geol, 194: 365-378.

Kretchsmar U. II., and McNutt R. II. (1971) A study of the Fe-Ti oxides in the Whitestone anorthosite. Dunchurch. Ontario. Can. J. Earth Sci, 8: 947-960.

Lindsley D. II. (1965) Iron-titanium oxides. Carnegie Inst. of Washington, Year Book, 64: 144-148.
Mitra S. and Ahmed S. S. (1990) Distribution and textural characteristics of the heavy minerals in the beach and dune sands of Cox's Bazar, Bangladesh. Jour. Geol. Soc. India, 36: 54-66.

Molinaroli E. and Basu A. (1987) Minerali opachi in sabbie fluviali olochemiche nelle corrispondenti rocce madri in due zone climaliche in U.S.A. Rend. Soc. Ital. Min. Perol, 42: 271-283.

Rao D. S., Murthy G. V. S., Rao K. V., Das D. and Chintalapudi S. N. (2002) Alteration characteristics of beach placer ilmenite from the Chatrapur coast, Orissa, India. Jour. Applied Geochemistry, 4(1): 47-49.

Rao D. S., Vijayakumar T. V., Prabhakar S., Bhaskar R. G. and Ghosh T. K. (2005) Alteration characteristics of ilmenites from South India. J. M.M.C.E. 4(1): 47-49.

Ramdohr P. (1980) The ore minerals and their intergrowths. 2nd Ed. (Pergamon Press, New York) 1980, pp. 1200.

Riezebos P. A. (1979) Compositional downstream variation of opaque and translucent heavy residues in some modem Rio Magdalena sands (Columbia). Sed. Geol, 24: 197-225.

Suresh Babu D. S., Thomas K. A., Mohan Das P. N. and Damodaran, A. D. (1994) Alteration of ilmenite in the Manavalakurichi deposits, India. Clays and Clay Minerals, 42: 567-571.

Wort M. J. and Jones M. P. (1981) Magnetic properties of ilmenite, detrital altered ilmenite and pseudorutile. Trans. Instn. Min. Metall, 90: 130-137.

Received : April 27, 2008;

Accepted : July 09, 2009 